\title{
PENGARUH PENDAPATAN MARGIN MURABAHAH TERHADAP PENINGKATAN MODAL BANK SYARI'AH MANDIRI
}

\author{
Trizuan, Sandi Andika \\ Sekolah Tinggi Ilmu Agama Islam Negeri (STAIN) Bengkalis \\ trizuan97@gmail.com, sandi.andika@gmail.com
}

\begin{abstract}
Murabahah financing is one of the most common types of contracts applied in Islamic banking financing activities. This is because most of the credit and financing provided by the banking sector in Indonesia relies on the consumer sector. The purpose of this study was to determine the effect of murabahah margin income on the increase in capital of Bank Syari'ah Mandiri. The research method used is a simple linear regression quantitative analysis. From the results of the coefficient of determination shows that murabahah margin income to increase the capital of Bank Syari'ah Mandiri has no significant effect, only contributing 6.6\% and the remaining $93.4 \%$ can be explained by other factors such as liabilities, wadi'ah demand deposits, wadi'ah savings, burdens and mudharabah savings.
\end{abstract}

Keywords: Murabahah Margin Revenue, Capital Increase, Bank Syari'ah Mandiri.

\begin{abstract}
ABSTRAK
Pembiayaan dengan akad murabahah merupakan salah satu jenis akad yang paling umum diterapkan dalam aktivitas pembiayaan perbankan syariah. Hal ini disebabkan karena sebagian besar kredit dan pembiayaan yang diberikan sektor perbankan di Indonesia bertumpu pada sektor konsumtif. Tujuan penelitian ini adalah untuk mengetahui pengaruh pendapatan margin murabahah terhadap peningkatan modal Bank Syari'ah Mandiri. Metode penelitian yang digunakan adalah analisis kuantitatif regresi linier sederhana. Dari hasil koefisien determinasi menunjukkan bahwa pendapatan margin murabahah terhadap peningkatan modal Bank Syari'ah Mandiri tidak berpengaruh signifikan, hanya berkontribusi sebesar $6,6 \%$ dan sisanya sebesar $93,4 \%$ dapat dijelaskan oleh faktor lain seperti liabilitas, giro wadi'ah, tabungan wadi'ah, beban dan tabungan mudharabah.
\end{abstract}

Kata Kunci: Pendapatan Margin Murabahah, Peningkatan Modal, Bank Syari'ah Mandiri.

\section{PENDAHULUAN}

Lembaga perbankan merupakan sebuah lembaga yang melaksanakan tiga fungsi utama, yaitu menerima simpanan uang, menyalurkan uang dan memberikan pelayanan pengiriman uang. Pada dasarnya ketiga fungsi tersebut sudah dilaksanakan pada zaman Rasulullah SAW. walaupun belum dikelola dengan baik. Oleh sebab itu, bisa dikatakan bahwa secara substansial fungsi bank 
ketika zaman Rasulullah SAW. sudah ada dalam sejarah perekonomian kaum muslimin. Pembiayaan yang dilakukan dengan akad yang sesuai dengan syari'ah telah menjadi bagian dari tradisi umat islam sejak zaman Rasulullah SAW. pelaksanaan seperti menerima penitipan harta, meminjam uang untuk keperluan konsumtif dan bisnis, serta melakukan pengiriman uang, telah lazim dilakukan pada zaman Rasulullah SAW. (Mardani 2015, 12).

Penerapan ekonomi syari'ah secara historis di Indonesia pada dasarnya ada sejak digulirkannya paket kebijakan Menteri Keuangan pada Desember 1983 atau yang dikenal dengan pakdes 1983. Pakdes ini memberi peluang kepada lembaga perbankan untuk memberikan kredit dengan bunga $0 \%$ (zero interest). Kemudian dilanjutkan oleh adanya paket Oktober 1988 yang intinya memberikan kemudahan untuk mendirikan bank-bank baru. Adanya kemudahan tersebut menimbulkan konsekuensi pendirian bank-bank baru dengan peningkatan jumlah yang signifikan. Namun baru pada tahun 1991 lahir bank berdasarkan prinsip syari'ah, yaitu bank Muamalat Indonesia (BMI).

BMI muncul dilatar belakangi oleh adanya rekomendasi lokakarya ulama tentang bunga bank dan berlangsung di Cisarua Bogor 19-22 Agustus 1990. Hasil lokakarya itu dibahas lebih mendalam pada Musyawarah Nasional (Munas) IV Mejelis Ulama Indonesia (MUI) yang berlangsung di Hotel Syahid Jaya, Jakarta, 22-25 Agustus 1990. Berdasarkan amanat Munas IV MUI dibentuk kelompok kerja (Pokja) untuk mendirikan Bank Syari'ah Indonesia. BMI pada waktu itu lebih dikenal dengan bank yang mendasarkan pada prinsip bagi hasil (Profit Sharing). Dasar hukum mengenai pendirian bank syari'ah di Indonesia pada waktu itu belum ada, hanya saja adanya paket deregulasi perbankan Oktober 1988 (pakto 88) dapat dijadikan acuan, mengingat dalam pakto itu telah diperkenankan adanya bank dengan bunga 0\% (zero interest). Kemudian pada 1992 keluar UU No.7 Tahun 1992 tentang perbankan yang secara implisit memberikan alternatif oprasional bank menggunakan prinsip bagi hasil. Hal ini ditindaklanjuti dengan dikeluarkannya Peraturan Pemerintah No. 72 Tahun 1992 tentang Bank Berdasarkan Bagi Hasil. Pada tahun 1998 Undang-Undang No. 7 Tahun 1992 diubah dengan UU No. 10 tahun 1998 yang secara tegas mengakui keberadaan bank yang berdasarkan prinsip syari'ah disamping bank konvensional. Tahun 1998 itulah tahun dimulainya sistem perbankan ganda (dual banking system). Dengan perkembangan yang signifikan perbankan syari'ah di Indonesia, maka pemerintah mengeluarkan Undang-Undang tersendiri tentang Perbankan Syari'ah, yaitu melalui UU No. 21 Tahun 2008 (Mardani 2015, 17-19).

Dari penjelesan diatas dapat kita pahami bahwa, munculnya perbankan/ekonomi Islam bertujuan untuk menghilangkan prinsip yang mengandung unsur riba. Yang mana setiap praktek yang mengandung unsur riba itu tidak diperbolehkan didalam agama islam. Seperti yang terkadung didalam AlQur'an, surah Al-Baqarah ayat 279 (Kemenag RI 2006):

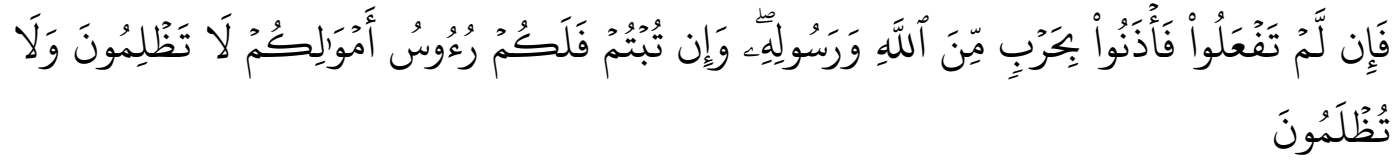

Artinya: "Maka jika kamu tidak mengerjakan (meninggalkan sisa riba), maka ketahuilah, bahwa Allah dan Rasul-Nya akan memerangimu. Dan jika kamu bertaubat (dari pengambilan riba), maka bagimu pokok hartamu; kamu tidak menganiaya dan tidak (pula) dianiaya”. 
Selain itu pula didalam kegiatan ekonomi, riba dapat mengakibatkan dampak yang sangat luar biasa. Contohnya didalam dunia perbankan, dimana jika perbankan menggunakan sistem bunga yang mengharuskan pembayaran bunga deposan sedangkan pemberian kredit mengalami kemacetan maka ini akan mempengaruhi keuangan perbankan yang mengakibatkan perbankan dilikuidasi karena tidak mampu membayar bunga deposan yang ada.

Pembiayaan dengan akad murabahah merupakan salah satu jenis akad yang paling umum diterapkan dalam aktivitas pembiayaan perbankan syariah. Boleh dikatakan produk ini merupakan produk andalan disetiap perbankan syariah di Indonesia. Hal ini disebabkan karena sebagian besar kredit dan pembiayaan yang diberikan sektor perbankan di Indonesia bertumpu pada sektor konsumtif. Porsi pembiayaan murabahah saat ini berkontribusi paling besar dari total pembiayaan Perbankan syariah, tentu sangat mempengaruhi baik buruknya sektor permodalan perbankan syariah.

Berdasarkan hal diatas maka penulis bertujuan untuk meneliti bagaimana pengaruh pendapatan margin murabahah terhadap peningkatan modal bank syariah. Manfaat yang diharapkan dari penelitian ini adalah mampu memberikan tambahan informasi, referensi, dan memperkaya pengetahuan ilmiah bagi akademisi, pihak perbankan, masyarakat dan peneliti-peneliti selanjutnya yang berminat untuk memperdalam dan mengembangkan penelitian ini menjadi lebih baik.

\section{TELAAH LITERATUR}

\section{Bank Syari'ah}

Bank berasal dari bahasa Italia banco yang artinya bangku. Bangku inilah yang dipergunakan bankir untuk melayani kegiatan oprasionalnya kepada para nasabah. Istilah bangku secara resmi dan populer menjadi bank. Bank termasuk perusahaan industri jasa karena produknya hanya memberikan pelayanan jasa kepada masyarakat (Hasibuan 2011, 1). Bank syariah terdiri dari dua kata, yaitu bank dan syari'ah. Secara terminologis bank adalah badan usaha yang menghimpun dana dari masyarakat dalam bentuk simpanan dan menyalurkannya kepada masyarakat dalam bentuk kredit/atau bentuk lainnya dalam rangka meningkatkan taraf hidup rakyat (Mardani 2015, 9).

Pengertian syari'ah secara etimologis berarti sumber air yang mengalir, kemudian kata tersebut digunakan untuk pengertian; hukum-hukum Allah yang diturunkannya untuk umat manusia (hamba Allah). Secara terminologis syari'ah yaitu hukum atau peraturan yang diturunkan Allah melalui Rasul-Nya yang mulia, untuk umat manusia, agar mereka keluar dari kegelapan kedalam terang dan mendapatkan petunjuk kearah yang lurus. Adapun yang dimaksud dengan prinsip syari'ah menurut undang-undang adalah prinsip hukum Islam dalam kegiatan perbankan berdasarkan fatwa yang dikeluarkan oleh lembaga yang memiliki kewenangan dalam menetapkan fatwa dalam bidang syari'ah (Mardani 2015, 1011).

Bank syari'ah adalah bank yang beroperasi sesuai dengan prinsip-prinsip syariat islam, atau dengan kata lain yaitu bank yang beroprasinya mengacu kepada ketentuan-ketentuan Islam (Al-qur'an dan Hadits). Dalam tata cara tersebut dijauhi praktek-praktek yang dikhawatirkan mengandung unsur-unsur riba untuk 
diisi dengan kegiatan-kegiatan investasi atas dasar bagi hasil dari pembiayaan perdangangan.

Prinsip syari'ah dalam kegiatan usaha bank syari'ah adalah aturan perjanjian berdasarkan hukum Islam antara bank dan pihak lain untuk penyimpanan dana atau pembiayaan kegiatan usaha dan kegiatan lainnya yang dinyatakan sesuai dengan syariat. Kegiatan usaha dengan prinsip syari'ah, antara lain (Hasibuan 2011, 40): Wadiah (titipan), Mudharabah (bagi hasil), Musyarakah (penyertaan), Ijarah (sewa beli), Salam (pembiayaan dimuka), Istishna (pembiayaan bertahap), hiwalah (anjak piutang), kafalah (garansi bank), rahn (gadai), sharf (transaksi valuta asing), qardh (pinjaman talangan), qardhul hasan (pinjaman sosial) dan Ujrah (fee).

\section{Pembiayaan Murabahah.}

Pengertian pembiayaan disebutkan dalam ketentuan Pasal 1 angka 12 Undang-Undang Nomor 7 Tahun 1992 sebagaimana telah diubah dengan UndangUndang Nomor 10 Tahun 1998, yaitu: "Pembiayaan berdasarkan prinsip syari'ah adalah penyediaan uang atau tagihan yang dipersamakan dengan itu berdasarkan persetujuan atau kesepakatan antara bank dengan pihak lain yang mewajibkan pihak yang dibiayai untuk mengembalikan uang atau tagihan tersebut setelah jangka waktu tertentu dengan imbalan atau bagi hasil".

Murabahah berasal dari bahas arab dengan akar kata ribh yang artinya keuntungan. Adapun menurut istilah Murabahah merupakan akad jual beli atas barang tertentu, dimana penjual menyebutkan harga jual yang terdiri atas harga pokok barang dan tingkat keuntungan tertentu atas barang, dimana harga jual tersebut disetujui pembeli. Dalam fatwa Dewan Syari'ah Nasional No. 04/DSNMUI/IV/2000 dan No. II/DSN-MUI/IX/2007 tentang jual beli murabahah disebutkan murabahah yaitu menjual suatu barang dengan menegaskan harga belinya kepada pembeli dan pembeli membayarnya dengan harga yang lenih sebagai laba (Soemitra 2019, 82).

Dalam pengertian lain, murabahah adalah salah satu bentuk jual beli yang bersifat amanah. Bentuk jual beli ini berlandaskan pada sabda Rasulullah SAW. dari syuaib ar Rumy RA.: "tiga hal yang didalamnya terdapat keberkahan: pertama, menjual dengan pembayaran tangguh (murabahah), kedua, muqarradhah (nama lain dari mudharabah) dan ketiga, mencampuri tepung dengan gandum untuk kepentingan rumah, bukan untuk diperjualbelikan" (Arifin 2009, 27).

Undang-Undang No. 21 Tahun 2008 tentang perbankan syari'ah memberikan definisi tentang murabahah, dalam penjelasan pasal 19 ayat (1) menyatakan akad murabahah adalah akad pembiayaan suatu barang dengan menegaskan harga belinya kepada pembeli dan pembeli membayar lebih sebagai keuntungan yang disepakati. Dengan demikian, karakteristik jual beli dengan akad murabahah adalah si penjual harus memberitahu tentang modal atau harga pemebelian barang dan menyatakan jumlah keuntungan yang ditambah pada biaya tersebut (Suadi 2018). Sedangkan untuk ketentuan umum dalam Pembiayaan murabahah telah diatur dalam Fatwa DSN No. 04/DSN-MUI/IV/2000. 


\section{Margin}

Margin adalah kenaikan bersih dari aset bersih sebagai akibat dari memegang aset yang mengalami peningkatan nilai selama periode yang dipilih oleh pernyataan pendapatan. Keuntungan juga bisa diperoleh dari pemindahan saling tergantung insidental yang sah dan yang tidak saling tergantung pemegang saham, atau pemegang-pemegang rekening investasi tak terbatas dan yang setara dengannya. Pengertian margin berdasarkan Kamus Besar Bahasa Indonesia Pusat Bahasa adalah laba kotor atau tingkat selisih antara biaya produksi dan harga jual di pasar (Anggadini 2011).

\section{Modal}

Dalam Kamus Besar Bahasa Indonesia "modal" didefinisikan sebagai uang pokok, atau uang yang dipakai sebagai induk untuk berniaga, melepas uang dan sebagainya. Definisi itupun memperkuat teori lama ekonomi mikro, dimana modal yang berbentuk uang (money) adalah salah satu dari faktor produksi, selain manusia (man), bahan baku (material), mesin (machine) serta prosedur dan teknologi (method) (Soekarno 2010, 1). Modal bagi bank yang didirikan dan berkantor pusat di Indonesia terdiri atas modal inti dan modal pelengkap. Adapun rincian komponen dari masing-masing modal tersebut adalah modal inti dan modal pelengkap (Usman 2001, 115-118).

\section{Hubungan Antara Pembiayaan dan Pendapatan}

Sedangkan pendapatan menurut PSAK No. 23 menyatakan bahwa pendapatan diukur dengan nilai wajar imbalan yang diterima atau yang dapat diterima. Pendapatan yang didapatkan oleh bank sendiri terdiri dari kontrak bagi hasil, kontrak jual beli, kontrak sewa (ijarah) dan jasa perbankan. Peningkatan pendapatan akan dapat dilihat melalui seberapa besar pembiayaan yang dikeluarkan oleh pihak bank. Jika pembiayaan yang diberikan besar dan pendapatan yang diterima kecil menurut Usman (2009) "besar kecilnya pembiayaan dapat mempengaruhi jumlah pendapatan yang diterima oleh bank. Ketika pembiayaan lancar maka dapat meningkatkan pendapatan bagi pihak bank yang dapat mendorong kinerja dalam perbankan".

\section{METODE PENELITIAN}

Jenis penelitian ini adalah penelitian kuantitatif. Variabel independen dalam penelitian ini adalah Pendapatan Margin Murabahah, sedangkan variabel dependennya adalah Peningkatan Modal Bank Syari'ah Mandiri. Penelitian ini dilaksanakan pada Bank Mandiri Syari'ah dari bulan Mei sampai dengan Juni 2019. Sampel penelitian adalah laporan keuangan triwulan Bank Mandiri Syari'ah dari tahun 2013-2018. Teknik pengumpulan data adalah dokumentasi dan studi pustaka. Kemudian untuk menganalisis data digunakan uji asumsi klasik (uji normalitas dan uji heteroskedastisitas), regresi linear sederhana, koefisien determinan dan uji hipotesis. 


\section{HASIL DAN PEMBAHASAN PENELITIAN}

Berdasarkan data yang telah ditentukan maka diperoleh data pembiayaan murabahah dan modal Bank Syari'ah Mandiri yang diperoleh dari Laporan Keuangan Triwulan PT. Bank Syari'ah Mandiri yang telah dipublikasi dari tahun 2013-2018.

Tabel 1 Laporan Keuangan Triwulan

Publikasi PT. Bank Syari'ah Mandiri Periode 2013-2018 (Dalam Juta Rupiah)

\begin{tabular}{|c|c|c|c|}
\hline Tahun & $\begin{array}{c}\text { Per } \\
\text { Triwulan }\end{array}$ & $\begin{array}{c}\text { Pendapatan } \\
\text { Margin } \\
\text { Murabahah }\end{array}$ & Modal \\
\hline \multirow{4}{*}{2013} & I & 853.978 & 55.479 .062 \\
\hline & II & 1.815 .446 & 58.483 .564 \\
\hline & III & 2.724 .387 & 61.810 .295 \\
\hline & IV & 3.773 .500 & 63.965 .361 \\
\hline \multirow{4}{*}{2014} & I & 976.287 & 63.009 .396 \\
\hline & II & 1.953 .358 & 62.786 .572 \\
\hline & III & 2.882 .917 & 65.368 .281 \\
\hline & IV & 3.873 .016 & 66.942 .422 \\
\hline \multirow{4}{*}{2015} & I & 921.438 & 67.151 .521 \\
\hline & II & 1.750 .901 & 66.953 .689 \\
\hline & III & 2.675 .807 & 67.120 .476 \\
\hline & IV & 3.635 .096 & 70.369 .709 \\
\hline \multirow{4}{*}{2016} & $\mathrm{I}$ & 931.242 & 71.548 .944 \\
\hline & II & 1.885 .098 & 72.022 .855 \\
\hline & III & 2.837 .844 & 74.241 .902 \\
\hline & IV & 3.898 .918 & 78.831 .722 \\
\hline \multirow{4}{*}{2017} & I & 1.005 .883 & 80.012 .307 \\
\hline & II & 2.098 .330 & 81.901 .309 \\
\hline & III & 3.147 .494 & 84.087 .348 \\
\hline & IV & 4.216 .447 & 87.939 .774 \\
\hline \multirow{4}{*}{2018} & I & 1.077 .450 & 92.976 .854 \\
\hline & II & 2.176 .602 & 92.813 .105 \\
\hline & III & 3.315 .728 & 93.347 .112 \\
\hline & IV & 4.483 .277 & 98.341 .116 \\
\hline
\end{tabular}




\section{Hasil Uji Normalitas}

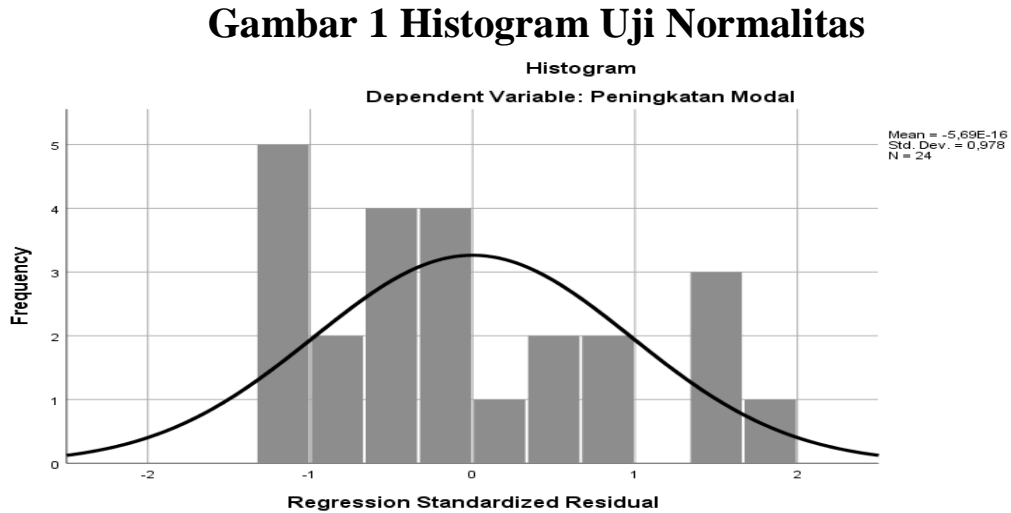

Sumber: Ouput SPSS

Berdasarkan gambar 1 di atas dapat dilihat bahwa membentuk kurva normal dan sebagian besar batangan berada dibawah kurva, maka dapat dikatakan bahwa variabel tersebut berdistribusi normal.

Gambar 2 Normal P-P Plot

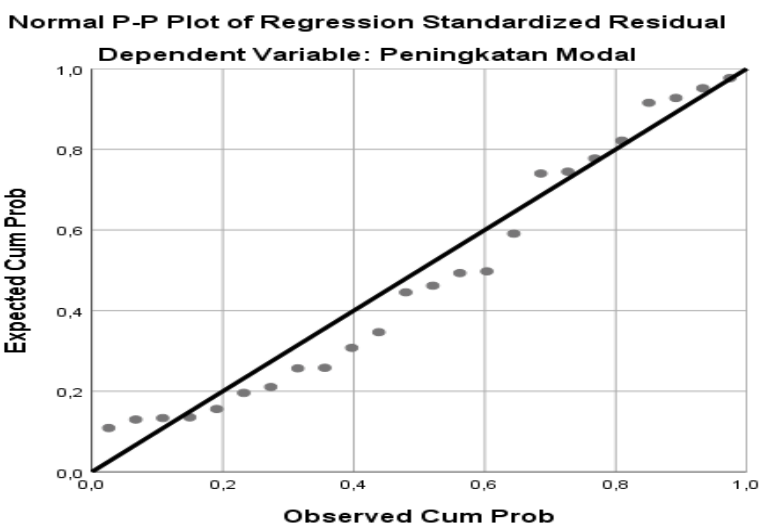

Sumber: Output SPSS

Berdasarkan gambar 2 dapat kita lihat bahwa, plot-plot mengikuti garis dan berada disekitar garis diagonal, yang menandakan bahwa nilai residual berdistribusi secara normal.

Tabel 2 Hasil Uji Normalitas Kolmogrov-Smirnov

\begin{tabular}{|c|c|c|}
\hline$N$ & & 24 \\
\hline Normal & Mean & ,0000000 \\
\hline Parameters $^{a, b}$ & Std. Deviation & 11609021,91539645 \\
\hline Most Extreme & Absolute & , 128 \\
\hline Differences & Positive &, 128 \\
\hline & Negative &,- 104 \\
\hline Test Statistic & & , 128 \\
\hline Asymp. Sig. (2. & iled) & $200^{\mathrm{c}, \mathrm{d}}$ \\
\hline $\begin{array}{l}\text { a. Test distribution is } \Lambda \\
\text { b. Calculated from dat } \\
\text { c. Lilliefors Significand } \\
\text { d. This is a lower boun }\end{array}$ & $\begin{array}{l}\text { Correction. } \\
\text { f the true significance. }\end{array}$ & \\
\hline
\end{tabular}


Berdasarkan tabel 2 dapat dilihat bahwa Asymp. Sig. (2-tield) pendapatan margin Murabahah mendapatkan rata-rata sebesar 0,200 yang menandakan bahwa nilainya lebih besar dari 0,05. Yang berarti dari uji Kolmogrov-Smirnov tersebut dapat kita ketahui bahwa nilai signifikan $0,200>0,05$ sehingga data dapat dikatakan berdistribusi normal.

\section{Hasil Uji Heteroskedastisitas}

Tabel 3 Hasil Uji Heterokedastisitas Metode Glesjer Coefficients $^{a}$

\begin{tabular}{|c|c|c|c|c|c|c|}
\hline & \multirow[t]{2}{*}{ Model } & \multicolumn{2}{|c|}{$\begin{array}{c}\text { Unstandardized } \\
\text { Coefficients }\end{array}$} & \multirow{2}{*}{$\begin{array}{c}\text { Standardized } \\
\text { Coefficients } \\
\text { Beta }\end{array}$} & \multirow[t]{2}{*}{$t$} & \multirow[t]{2}{*}{ Sig. } \\
\hline & & $\boldsymbol{B}$ & Std. Error & & & \\
\hline \multirow[t]{4}{*}{1} & (Constant) & $-6,830 \mathrm{E}-9$ & 5749792,522 & & ,000 & 1,000 \\
\hline & Pendapatan &, 000 & 2,124 & ,000 & ,000 & 1,000 \\
\hline & Margin & & & & & \\
\hline & Murabahah & & & & & \\
\hline
\end{tabular}

Berdasarkan tabel 3 di atas dapat dijelaskan bahwa pendapatan margin murabahah lebih besar dari 0,05. Pada output dapat dilihat bahwa, nilai signifikan adalah 1,000 >0,05, sehingga bisa dikatakan tidak terjadi heterokedastisitas.

\section{Hasil Koefisien Determinasi $\left(\mathbf{R}^{2}\right)$}

Tabel 4 Hasil Uji Koefisien Determinasi

\begin{tabular}{ccccc}
\multicolumn{5}{c}{ Model Summary $^{\boldsymbol{b}}$} \\
\hline Model & $\boldsymbol{R}$ & $\boldsymbol{R}$ & $\begin{array}{c}\text { Adjusted } \boldsymbol{R} \\
\text { Square }\end{array}$ & $\begin{array}{c}\text { Std. Error of the } \\
\text { Estimate }\end{array}$ \\
\hline 1 &, $327^{\mathrm{a}}$ &, 107 &, 066 & 11869931,38936 \\
\hline
\end{tabular}

a. Predictors: (Constant), Pendapatan Margin Murabahah

b. Dependent Variable: Peningkatan Modal

Sumber: Output SPSS

Berdasarkan tabel 4 di atas dapat dilihat bahwa nilai Adjused $R$ Square adalah 0.066. Hal ini menunjukkan bahwa peningkatan modal Bank Syari'ah Mandiri dipengaruhi oleh pendapatan margin murabahah sebesar 6,6\% yang artinya tidak adanya hubungan yang kuat antara variabel bebas dengan variabel terikat. Karena pendapatan margin murabahah hanya memberi kontribusi sebesar $6,6 \%$ terhadap peningkatan modal Bank Syari'ah Mandiri. Sedangkan sisanya 93,4\% diterangkan oleh faktor lain diluar model yang penulis lakukan. 


\section{Hasil Uji Hipotesis.}

\begin{tabular}{|c|c|c|c|c|c|c|}
\hline & \multicolumn{6}{|c|}{$\begin{array}{c}\text { Tabel } 5 \text { Hasil Uji t } \\
\text { Coefficients }^{\mathrm{a}}\end{array}$} \\
\hline & \multirow[t]{2}{*}{ Model } & \multicolumn{2}{|c|}{ Unstandardized Coefficients } & \multirow{2}{*}{$\begin{array}{c}\text { Standardized } \\
\text { Coefficients } \\
\text { Beta } \\
\end{array}$} & \multirow[t]{2}{*}{$t$} & \multirow[t]{2}{*}{ Sig. } \\
\hline & & $\boldsymbol{B}$ & Std. Error & & & \\
\hline \multirow[t]{2}{*}{1} & $\begin{array}{l}\text { (Constant) } \\
\text { Pendapatan }\end{array}$ & 65612621,326 & 5749792,522 & & 11,411 &, 000 \\
\hline & $\begin{array}{l}\text { Margin } \\
\text { Murabahah }\end{array}$ & 3,443 & 2,124 &, 327 & 1,621 & ,119 \\
\hline
\end{tabular}

Berdasarkan tabel 5 dapat dilihat bahwa hasil uji t menunjukkan bahwa nilai signifikannya adalah 0,119 . Hipotesisnya adalah:

$\mathrm{H}_{0}$ : Pendapatan margin murabahah tidak berpengaruh signifikan terhadap peningkatan modal Bank Syari'ah Mandiri

$\mathrm{H}_{1}$ : Pendapatan margin murabahah tidak berpengaruh signifikan terhadap peningkatan modal Bank Syari'ah Mandiri.

Pengaruh pendapatan margin murabahah dari hasil pengujian regresi menunjukkan bahwa $t_{\text {hitung }}<\mathrm{t}_{\text {tabel }}(1,621<2,074)$ dan nilai signifikan $(0,119>$ 0,05) dengan demikian dapat dikatakan bahwa $\mathrm{H}_{0}$ terima dan $\mathrm{H}_{1}$ ditolak, maka dengan demikian dapat diketahui bahwa variabel pendapatan margin murabahah tidak berpengaruh secara signifikan terhadap peningkatan modal Bank Syari'ah Mandiri.

\section{Hasil Uji Regresi Linier Sederhana}

Berdasarkan tabel 5 dapat digunakan untuk menggambarkan persamaan regresi sebagai berikut:

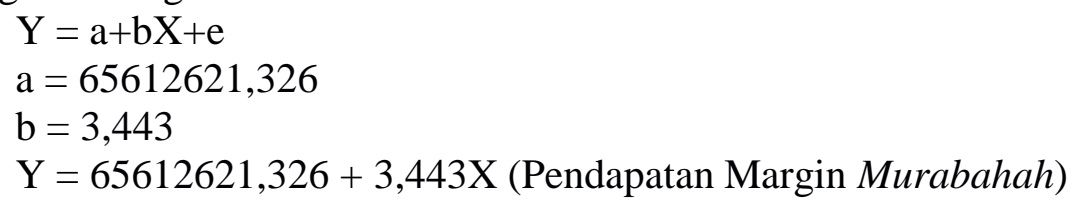

Koefisien regresi pendapatan margin murabahah sebesar 3,443 artinya setiap penambahan 1 nilai pendapata margin murabahah (karena hasil positif) akan mempengaruhi peningkatan modal bank sebesar 6,6\%. Dengan kata lain bahwa pendapatan margin murabahah tidak berpengaruh signifikan terhadap peningkatan modal Bank Syari'ah Mandiri. sisanya 93,4\% dapat dijelaskan oleh faktor lain yang tidak disebutkan dalam model regresi ini.

\section{KESIMPULAN}

Berdasarkan literatur yang ada dapat disimpulkan bahwa margin murabahah merupakan selisih harga antara biaya produksi dan biaya jual atau biaya prolehan dengan harga jual. Kemudian dari hasil analisis data yang dilakukan ternyata Pendapatan Margin Murabahah tidak berpengaruh signifikan terhadap Peningkatan Modal Bank Syari'ah Mandiri, yang mana Pendapatan Margin Murabahah hanya berkontribusi sebesar 6,6\% dan sisanya sebesar 93,4\% 
disebabkan oleh faktor lain seperti liabilitas, giro wadi'ah, tabungan wadi'ah, beban dan tabungan mudharabah.

\section{DAFTAR PUSTAKA}

Andrianto dan Anang Firmansyah. 2019. Manajemen Bank Syari'ah; Implementasi Teori dan Praktek. Pasuruan: Qiara Media.

Anggadini, Sri Dewi. 2011. "Penerapan Margin Pembiayaan Murabahah Pada BMT As-Salam Pacet-Cianjur”. Majalah Ilmiah UNIKOM 9 (2), 187-198.

Ansofino, Jolianis, Yolamalinda dan Hagi Arfilindo. 2016. Buku Ajar Ekonometrika, Ed-1, Cet-1. Yogyakarta: Deepublish.

Arifin, Zainul. 2009. Dasar-Dasar Manajemen Bank Syari'ah, cet-7. Jakarta: Azkia Publisher.

Fuad, Anis dan Kandung Sapto Nugroho. 2014. Panduan Praktis Penelitian Kualitatif. Yogyakarta: Graha Ilmu.

Hasibuan, Melayu S.P. 2011. Dasar-Dasar Perbankan. Jakarta: PT. Bumi Aksara.

Ikit. 2015. Akuntansi Penghimpunan Dana Bank Syari'ah, ed.1, cet.1. Yogyakarta: Deepublish.

Ismail, Fajri. 2018. Statistika: Untuk Penelitian Pendidikan Dan Ilmu-Ilmu Sosial, Cet, Ke-1. Jakarta: Prenada Media.

Kementerian Agama RI. 2006. Al-Quran. Jakarta: PT. Karya Toha Putra.

Mardani. 2015. Aspek Hukum Lembaga Keuangan Syari'ah Di Indonesia. Jakarta: Kencana Pranada Group.

Muhammad. 2008. Metodologi Penelitian Ekonomi Islam: Dilengkapi dengan Contoh-contoh Aplikasi: Proposal Penelitian dan Laporannya, Ed.1. Jakarta: Rajawali Press.

Pusat Bahasa. 2005. Kamus Besar Bahasa Indonesia, Edisi Ketiga. Jakarta: Balai Pustaka.

Soekarno, Supriyono. 2010. Cara Cepat Dapat Modal: Buku Wajib Untuk Memulai atau Mengembangkan Bisnis Anda. Jakarta: PT. Gramedia.

Soemitra, Andri. 2019. Hukum Ekonomi Syari'ah dan Figh Muamalah di Lembaga Keuangan dan Bisnis Kontemporer, edisi pertama, cet-1. Jakarta: Kencana Prenada.

Suadi, Amran. 2018. Penyelesaian Sengketa Ekonomi Syari'ah: Penemuan dan Kaidah Hukum, cet-1. Jakarta: Pranada Media.

Usman, Rachmadi. 2001. "Aspek-Aspek Hukum Perbankan Di Indonesia". Jakarta: PT. Gramedia Pustaka Utama.

Usman, Rachmadi. 2009. Produk dan Akad Perbankan Syari'ah di Indonesia: Implementasi dan Aspek Hukum, cet-1. Bandung: PT. Citra Aditya Bakti. 